\title{
Wound dehiscence after penetrating keratoplasty
}

\author{
Evin Şingar Özdemir, M.D., ${ }^{1}$ ๑ Ayşe Burcu, M.D., ${ }^{1}$ ¿ Züleyha Yalnız Akkaya, M.D., ${ }^{1}$ \\ Barış Oral, M.D., ${ }^{2}$ (b) Firdevs Örnek, M.D. ${ }^{1}$
}

${ }^{1}$ Department of Ophthalmology, Ankara Training and Research Hospital, Ankara-Turkey

${ }^{2}$ Department of Ophthalmology, Ağrı State Hospital, Ağrı-Turkey

\begin{abstract}
BACKGROUND: The purpose of this study was to investigate factors affecting wound dehiscence due to blunt trauma following penetrating keratoplasty (PK) and the clinical outcomes.

METHODS: The medical records of patients who experienced blunt traumatic wound dehiscence after PK between 1995 and 2015 were analyzed retrospectively. The incidence and etiology of the trauma, the time interval between PK and globe rupture, final graft clarity, best-corrected visual acuity, complications, secondary surgeries, and factors potentially affecting wound dehiscence size were recorded.

RESULTS: This study included a total of 39 patients with a mean age of $42.66 \pm 16.66$ years, of whom 23 patients were male and 16 patients were female. The incidence of wound dehiscence was $2.3 \%$. The mean interval between the PK procedure and wound dehiscence was $25.91 \pm 47.24$ months and the mean follow-up time was $34.43 \pm 51.02$ months. The most common trauma mechanism was force with a blunt object (53.8\%) and the most frequent site of wound dehiscence was the temporal quadrant (30.8\%), the wound ranging from $30^{\circ}$ to $270^{\circ}$ in size. The patients were divided into 4 groups according to wound dehiscence size. As the size of the wound dehiscence size increased, the male ratio increased, wound dehiscence was more commonly located in the nasal and superior quadrants, lens injury and posterior segment complications were more frequent, and graft transparency was achieved at a lower rate.
\end{abstract}

CONCLUSION: Traumatic wound dehiscence after PK is rare, but may lead to serious, lifelong consequences, including eye loss. Patients should be well informed about the risks and potential sequelae of wound dehiscence.

Keywords: Penetrating keratoplasty; trauma; wound dehiscence.

\section{INTRODUCTION}

Wound dehiscence after penetrating keratoplasty (PK) is a rare but well-known complication, suggesting that the grafthost interface does not regain the tensile strength of primary corneal tissue. ${ }^{[1-3]}$ This complication typically occurs in the early postoperative period, and the risk factors include premature suture removal, wound healing abnormalities, suddenly increased intraocular pressure, corneal edema, and trauma. ${ }^{[4-6]}$ Delayed occurrence in the postoperative period is uncommon, and it typically occurs as a result of direct trauma or increased intraocular pressure due to glaucoma. ${ }^{[3-6]}$
Several studies have previously identified many risk factors for wound dehiscence (spontaneous or traumatic) after PK, such as age, preoperative indications, increased intraocular pressure, postoperative steroid use, and the timing of suture removal. ${ }^{[-11]}$ Intraocular tissues are more severely affected as the size of wound dehiscence increases. ${ }^{[2]}$ This study is a description of the clinical features of corneal wound dehiscence due to blunt trauma after PK and factors that can affect wound dehiscence and the outcomes.

\section{MATERIALS AND METHODS}

This retrospective, non-comparative study was approved by the human research ethics committee at Ankara Training

Cite this article as: Şingar Özdemir E, Burcu A, Yalnız Akkaya Z, Oral B, Örnek F. Wound dehiscence after penetrating keratoplasty. Ulus Travma Acil Cerrahi Derg 2018;24:563-568.

Address for correspondence: Evin Singar Özdemir, M.D.

Sükriye Mah., Ulucanlara Cad., Ankara Eğitim ve Araştırma Hastanesi, Altındağ, 06340 Ankara, Turkey

Tel: +90 312 - $5953491 \quad$ E-mail: evinsingar@yahoo.com

Ulus Travma Acil Cerrahi Derg 2018;24(6):563-568 DOI: 10.5505/tjtes.2018.44450 Submitted: 19.03.2017 Accepted: 09.04.2018 Online: 10.04.2018

Copyright 2018 Turkish Association of Trauma and Emergency Surgery 
and Research Hospital and it conformed to the principles of the Declaration of Helsinki (clinical trial number: 5308). The medical records of 1697 patients who underwent PK in the clinic between January I, 1995 and December 3I, 2015 were retrospectively screened. Patients who experienced wound dehiscence related to blunt ocular trauma after PK were included in this study. Patients who had wound dehiscence as a result of nontraumatic loosening or removal of sutures, penetrating injury, and those who did not experience wound dehiscence after trauma were excluded from the study.

Following the trauma, the wound was repaired under general anesthesia with interrupted or continuous 10/0 nylon sutures according to the state of the eye. Anterior vitrectomy, crystalline lens extraction, or iris repositioning was performed in the same or another session, as indicated.

Patients were assigned to 4 groups according to the size of the wound dehiscence: Group A comprised patients with a wound dehiscence $\leq 60^{\circ}$, Group B was made up of patients with a wound dehiscence of between $60^{\circ}$ and $120^{\circ}$, Group C was composed of patients with a wound dehiscence between $120^{\circ}$ and $180^{\circ}$, and patients with wound dehiscence $>180^{\circ}$ were included in Group D.

Details of the patient's age, sex, involved eye, reason for PK, suturing technique, type of trauma, the interval between keratoplasty and trauma, extent of the wound dehiscence, location of the dehiscence, presence of sutures and use of a topical steroid and cyclosporin A (CsA) at the time of trauma, repair surgery, resuturation or resuturation with other procedures), preoperative and postoperative best corrected visual acuity (BCVA), and graft clarity were recorded. Graft clarity was based on the transparency of the central part of the graft. The graft was also accepted as transparent if astigmatism secondary to the peripheral scar of the graft could be corrected with glasses or contact lenses and the scar did not progress to the pupillary area.

SPSS for Windows, Version 16.0. (SPSS Inc., Chicago, IL, USA) software was used to perform statistical analyses using frequency tables, descriptive tables, Pearson's chi-squared, ttests and one-way analysis of variance. A value of $p<0.05$ was accepted as statistically significant.

\section{RESULTS}

This study included 39 eyes of 39 patients who experienced blunt trauma after undergoing PK. The demographic features of the patients are shown in Table I. The technique used was a running suture in $3 \mathrm{I}$ traumatized eyes $(79.5 \%)$ and an interrupted PK suture in 8 eyes (20.5\%). The sutures were still present in $24(61.5 \%)$ cases, and in 19 of those patients the suture opened at the time of trauma. In all, 23 patients were using topical steroids (59\%) and 14 were using a topical CsA (Restasis; Allergan, Inc., Irvine, CA, USA) (35.9\%) at the time of the trauma. Topical medication was in use to control increased intraocular pressure before the trauma in 2 cases (5.1\%). The most frequent site of wound dehiscence was the temporal region, seen in 12 cases $(30.8 \%)$, as illustrated in Table 2.

The factors affecting wound dehiscence size are shown in Table 2. The size of the wound dehiscence was not significantly correlated to age $(p=0.89)$, PK indication $(p=0.15)$, trauma etiology $(p=0.1 \mathrm{I})$, time to trauma after $\mathrm{PK}(p=0.83)$, PK suture technique $(p=0.83)$, increased intraocular pressure after PK $(p=0.56)$, presence of sutures at the time of trauma $(p=0.67)$, or the use of a topical steroid $(p=0.63)$ or topical CsA $(p=0.38)$. Wound dehiscence of less than $120^{\circ}$ was more common in females, while wound dehiscence of more than $120^{\circ}$ was significantly more common in male pa-

Table I. The demographic features of the patients

\begin{tabular}{|c|c|}
\hline \multicolumn{2}{|l|}{ Characteristics } \\
\hline Gender (female/male) & $16 / 23$ \\
\hline Age (years), Mean $\pm S D$ (range) & $\begin{array}{c}42.66 \pm 16.66 \\
(14-75)\end{array}$ \\
\hline Lateralization (right/left eye), n (\%) & $21 / 18$ \\
\hline \multicolumn{2}{|l|}{ Indication for PK } \\
\hline Keratoconus & $14(35.9)$ \\
\hline \multicolumn{2}{|l|}{ Corneal scar secondary to perforating } \\
\hline eye injury & $6(15.4)$ \\
\hline Corneal scar due to herpetic keratitis & $5(12.8)$ \\
\hline Nonspecific corneal leucoma & $5(12.8)$ \\
\hline Bullous keratopathy & $3(7.7)$ \\
\hline Corneal descemetocele & $2(5.1)$ \\
\hline Corneal dystrophy & $2(5.1)$ \\
\hline \multicolumn{2}{|l|}{ Corneal perforation (secondary to dry } \\
\hline eye and buphthalmos) & $2(5.1)$ \\
\hline Time between PK and trauma (months), & $25.91 \pm 47.24$ \\
\hline Mean $\pm S D$ (range) & $(0.30-240)$ \\
\hline Follow-up time after repair (months), & $34.43 \pm 51.02$ \\
\hline Mean $\pm S D$, (range) & $(12-244)$ \\
\hline \multicolumn{2}{|l|}{ Trauma incidence according to time after PK } \\
\hline$\leq \mathrm{I}$ month & $2(5.1 \%)$ \\
\hline I-6 months & $8(20.5 \%)$ \\
\hline $6-12$ months & $13(33.3 \%)$ \\
\hline I2-24 months & $8(20.5 \%)$ \\
\hline $24-60$ months & $4(10.3 \%)$ \\
\hline$>60$ months & $4(10.3 \%)$ \\
\hline The size of wound dehiscence (degrees), & $149.86 \pm 80.96^{\circ}$ \\
\hline Mean $\pm S D$ (range) & $\left(30^{\circ}-360^{\circ}\right)$ \\
\hline
\end{tabular}

PK: Penetrating keratoplasty; SD: Standard deviation. 
Table 2. Factors affecting traumatic wound dehiscence after penetrating keratoplasty

\begin{tabular}{|c|c|c|c|c|c|}
\hline & \multicolumn{4}{|c|}{ Wound dehiscence size } & \multirow[t]{2}{*}{$\mathbf{p}$} \\
\hline & $<60^{\circ}(n=6)$ & $\geq 60^{\circ}-<120^{\circ}(\mathrm{n}=13)$ & $\geq 120^{\circ}-<180^{\circ}(n=I I)$ & $\leq 180^{\circ}(n=9)$ & \\
\hline Mean age (years) & $45.16 \pm 11.07$ & $44.53 \pm 20.81$ & $41.45 \pm 18.00$ & $39.77 \pm 12.9$ & 0.89 \\
\hline Gender (female/male) & $5 / 1$ & $7 / 6$ & $3 / 8$ & $1 / 8$ & 0.023 \\
\hline Indication for PK & & & & & 0.15 \\
\hline Keratoconus & 2 & 6 & 4 & 2 & \\
\hline Other & 4 & 7 & 7 & 7 & \\
\hline Etiology of trauma & & & & & 0.11 \\
\hline Manual blunt trauma & 2 & 6 & 3 & 1 & \\
\hline Blunt object & 4 & 4 & 7 & 6 & \\
\hline Fall & - & 3 & 1 & - & \\
\hline Traffic accident (in-vehicle) & - & - & - & 2 & \\
\hline Time interval between PK and trauma & & & & & 0.83 \\
\hline$\geq 12$ months & 5 & 7 & 6 & 5 & \\
\hline$<12$ months & 1 & 6 & 5 & 4 & \\
\hline Wound dehiscence site & & & & & 0.031 \\
\hline Superior & - & 1 & 1 & 1 & \\
\hline Inferior & 3 & - & 3 & 3 & \\
\hline Nasal & - & 1 & 2 & 3 & \\
\hline Temporal & - & 5 & 5 & 2 & \\
\hline Inferotemporal & 1 & 2 & - & - & \\
\hline Superotemporal & I & - & - & - & \\
\hline Inferonasal & - & 4 & - & - & \\
\hline Superonasal & 1 & - & - & - & \\
\hline \multicolumn{6}{|l|}{ PK suture technique } \\
\hline Continuous/interrupted & $5 / 1$ & $10 / 3$ & $8 / 3$ & $8 / 1$ & 0.83 \\
\hline Increased intraocular pressure after PK & - & - & 1 & 1 & 0.56 \\
\hline Presence of sutures at the time of trauma & 5 & 8 & 6 & 5 & 0.67 \\
\hline Topical steroids use & 5 & 7 & 6 & 5 & 0.63 \\
\hline Topical CsA use & 2 & 5 & 2 & 5 & 0.38 \\
\hline
\end{tabular}

PK: Penetrating keratoplasty; CsA: Cyclosporin A.

tients $(p=0.023)$. There was a significant correlation between wound dehiscence size and the quadrant affected by trauma $(p=0.03 \mathrm{I})$. Wound dehiscence of $60^{\circ}$ or less was most common in the inferior quadrant, dehiscence of $60^{\circ}$ to $180^{\circ}$ was most common in the temporal quadrant, and wound dehiscence of more than $180^{\circ}$ was most common in the inferior and nasal quadrants.

The complications occurring during and after surgery and graft survival are provided in Table 3. As the size of the wound dehiscence size increased, lens injury $(p=0.028)$ and posterior segment injuries $(p=0.017)$ became more common. Posterior segment complications did not occur at less than $120^{\circ}$ and were more common in wounds that were $120^{\circ}$ or greater. Repeat keratoplasty due to tissue loss was performed during the repair for 2 patients. Evisceration was performed in 5 cases ( 3 as a primary treatment and due to endophthalmitis in 2).

Corneal clarity was established in $24(61.5 \%)$ eyes at the last visit. Graft failure occurred due to irreversible graft rejection $(n=4)$, endothelial cell loss $(n=6)$, and traumatic endophthalmitis $(n=2)$. Among all of the evaluated parameters, only wound size $(p=0.04)$ and posterior segment injuries $(p=0.008)$ significantly affected the rate of graft survival.

The mean logMAR BCVA was $2.08 \pm 0.82$ before PK, $1.15 \pm$ 0.83 at the last visit before the trauma, and $1.25 \pm 1.12$ at the final visit after the trauma. In the current study, the mean BCVA at the last visit following the trauma was statistically better than the mean BCVA before keratoplasty 
Table 3. The size of trauma-induced wound dehiscence complications during and after surgery graft survival

\begin{tabular}{|c|c|c|c|c|c|}
\hline & \multicolumn{4}{|c|}{ Wound dehiscence size } & \multirow[t]{2}{*}{$\mathbf{p}$} \\
\hline & $<60^{\circ}(\mathrm{n}=6)$ & $\geq 60^{\circ}-<120^{\circ}(n=13)$ & $\geq 120^{\circ}-<180^{\circ}(n=I I)$ & $\leq 180^{\circ}(n=9)$ & \\
\hline Anterior segment complications & & & & & 0.001 \\
\hline Hyphema & 1 & - & 1 & 2 & \\
\hline Iris prolapse & 1 & 2 & 3 & 5 & \\
\hline Lens damage and vitreous prolapse & 1 & 2 & 6 & 7 & \\
\hline Posterior segment complications & & & & & 0.017 \\
\hline Vitreous hemorrhage & - & - & 2 & I & \\
\hline Choroidal detachment & - & - & I & - & \\
\hline Retinal detachment & - & - & - & 2 & \\
\hline Graft survival & & & & & 0.041 \\
\hline Graft transparency & 4 & 10 & 9 & 3 & \\
\hline Graft failure & 2 & 3 & $2^{*}$ & $6^{* *}$ & \\
\hline
\end{tabular}

*The number of patients who underwent evisceration as primary treatment.

$(p=0.003)$, but worse than the mean BCVA before the trauma $(p=0.048)$.

\section{DISCUSSION}

In this study, we examined factors that could affect the size of wound dehiscence and the clinical features and outcomes of 39 PK patients who had blunt trauma-related wound dehiscence. During the 20-year period, the incidence of traumatic wound dehiscence following PK was approximately $2.3 \%$ $(39 / 1697)$, similar to the previously reported incidence rate of $0.6 \%$ to $5.8 \% .^{[2,10,12-15]}$

Although it is unknown just when a wound site regains original strength after PK, it has been reported that the strength of a post-PK cornea reaches $50 \%$ of the strength of a normal intact cornea by the 100 th day, and $70 \%$ by the $6^{\text {th }}$ month. ${ }^{[12]}$ Thus, the same trauma mechanism may lead to different consequences due to the time elapsed since the PK procedure and other factors affecting wound healing, such as advanced age, the indication for PK, the PK suture technique, premature suture removal, prolonged topical steroid use, topical CsA use, or the presence of glaucoma. ${ }^{[1-13,16-20]}$

Proper wound apposition is most important for wound strength in the early period after PK; factors influencing wound healing and apposition become prominent at later stages. Although previous studies have reported that wound dehiscence at the graft site developed between 3 days and 33 years after PK surgery, ${ }^{[3,13]}$ most traumatic wound ruptures occur within the first year, with the first I month and the interval after suture removal being the most risky periods. ${ }^{[13,15]}$ In our study, most of the traumatic ruptures occurred during the first year (58.9\%), especially between 6 and 12 months after PK (33.3\%).
Our study demonstrated that in women, wound dehiscence of less than $120^{\circ}$ was significantly more common, while a dehiscence of greater than $120^{\circ}$ was more frequently seen in men $(p=0.023)$. We attributed this finding to a quick return to daily activities (particularly outdoor activities) before complete wound healing due to rapid visual recovery, particularly in young male patients.

Long-term topical steroid use may delay wound healing. [3,9,10,21] There are several studies in which topical CsA did not delay corneal wound healing. ${ }^{[19,22]}$ In the present study, 59\% of the patients had a history of topical steroid use and $35.9 \%$ had used topical CsA. Kartal et al. ${ }^{[23]}$ did not find a correlation between traumatic wound dehiscence size and steroid use. Similarly, we found no such association for either topical steroids or CsA ( $p=0.63, p=0.38)$. We attributed the absence of this relationship to the presence of sutures at the wound site during the first year when the use of topical steroids is greatest.

It has been reported that corneal sutures are important for establishing the continuity of the graft-host junction, even years later. ${ }^{[13]}$ Lam et al. ${ }^{[13]}$ reported that a larger dehiscence and a graft without sutures in place at the time of trauma was more likely to fail, had more posterior segment damage, and a poorer visual outcome. The risk of traumatic corneal graft rupture is significant and is associated with a poor visual outcome. Kawashima et al. ${ }^{[18]}$ reported that globe rupture occurred despite the presence of sutures (51.2\%), and that no significant relationship was found between the presence or absence of sutures and the occurrence of wound dehiscence. In our study, sutures were present in $61.5 \%$ of the patients and suture presence did not appear to influence wound dehiscence size $(p=0.83)$. 
Previous studies have demonstrated that wound dehiscence occurred most frequently at the graft-host junction. ${ }^{[23,24]}$ It has been reported that wound dehiscence is more common in the inferior half of the cornea due to the lack of protection from the eyebrow, nose, and cheek. ${ }^{[3]}$ In our study, all of the instances of traumatic wound dehiscence occurred at the graft-host junction, and the most commonly involved quadrants, in descending order of frequency, were the temporal, lower, nasal, and upper quadrants. Dehiscence observed at the quadrant of trauma was attributed to impaired endurance of the wound site following PK even years later. There was a significant correlation between dehiscence size and the trauma quadrant $(p=0.03)$. As the size of the dehiscence increased, it was more commonly observed in the nasal and upper quadrants, where dehiscence is usually less visible due to the protective effect of the surrounding bony structures. We attributed this finding to a lower mean age and a greater male-to-female ratio, as males are typically exposed to more serious episodes of trauma.

In our study, graft transparency was achieved in 24 of 39 patients $(61.5 \%)$, and this ratio is consistent with the literature (range: $20 \%-100 \%$ ). ${ }^{[1,8,9]}$ In eyes exposed to trauma after PK, the degree of endothelial injury depends on the direct effects of the trauma, lens injury, vitreous loss, wound size, and timing of the repair. ${ }^{[1,13,25]}$ It was determined that wound dehiscence size $(p=0.04)$ and the development of posterior segment complications at the time of trauma $(p=0.008)$ significantly affected graft transparency. Lam et al. ${ }^{[13]}$ reported that graft transparency could not be achieved in any of the patients with a wound dehiscence of $180^{\circ}$ or more. Tran et al. ${ }^{[16]}$ demonstrated that extensive dehiscence was more prevalent in patients with injury to the lens and to the posterior segment. We found that with a greater dehiscence size and with posterior segment involvement, the achievement of graft transparency was reduced. We attributed this finding to a greater prevalence of lens and posterior segment complications with resultant cell loss as wound dehiscence size increased.

Trauma severity and graft survival, and posterior segment complications have been reported to be the major factors determining BCVA..$^{[1,2,4,7,13,23]}$ A significant difference was found in the BCVA values of the 4 groups after the trauma as lens injury $(p=0.028)$ and posterior segment complications $(p=0.028)$ became more prevalent and graft survival was reduced $(p=0.04)$ with increasing wound dehiscence.

As there are many factors that may affect wound apposition, the time required for wound endurance to return to normal is different in every patient. Wound dehiscence size and outcomes vary. We found that most traumatic ruptures occurred during the first year after PK. We did not find a specific factor affecting the size of wound dehiscence except male sex. As the size of the wound dehiscence increased, it was more commonly seen in the nasal and upper quad- rants, the incidence of posterior segment complications was greater, and graft survival was reduced. Patients who will undergo PK should be warned about measures to prevent eye trauma, and protective surgeries (lamellar surgery) should be performed when possible in order to achieve better globe integrity.

\section{Acknowledgement}

Financial support: The authors declare that they did not receive a specific grant from any funding agency in the public, commercial, or not-for-public sectors for this research.

Conflict of interest: None declared.

\section{REFERENCES}

1. Foroutan AR, Gheibi GH, Joshaghani M, Ahadian A, Foroutan P. Traumatic wound dehiscence and lens extrusion after penetrating keratoplasty. Cornea 2009;28:1097-9. [CrossRef]

2. Murata N, Yokogawa H, Kobayashi A, Yamazaki N, Sugiyama K. Clinical features of single and repeated globe rupture after penetrating keratoplasty. Clin Ophthalmol 2013;7:461-5.

3. Das S, Whiting M, Taylor HR. Corneal wound dehiscence after penetrating keratoplasty. Cornea 2007;26:526-9. [CrossRef]

4. Pettinelli DJ, Starr CE, Stark WJ. Late traumatic corneal wound dehiscence after penetrating keratoplasty. Arch Ophthalmol 2005;123:853-6.

5. Binder PS, Abel R Jr, Polack FM, Kaufman HE. Keratoplasty wound separations. Am J Ophthalmol 1975;80:109-15. [CrossRef]

6. Friedman AH. Late traumatic wound rupture following successful partial penetrating keratoplasty. Am J Ophthalmol 1973;75:117-20. [CrossRef]

7. Williams MA, Gawley SD, Jackson AJ, Frazer DG. Traumatic graft dehiscence after penetrating keratoplasty. Ophthalmology 2008;115:2768. [CrossRef]

8. Rohrbach JM, Weidle EG, Steuhl KP, Meilinger S, Pleyer U. Traumatic wound dehiscence after penetrating keratoplasty. Acta Ophthalmol Scand 1996;74:501-5. [CrossRef]

9. Topping TM, Stark WJ, Maumenee E, Kenyon KR. Traumatic wound dehiscence following penetrating keratoplasty. $\mathrm{Br} \mathrm{J}$ Ophthalmol 1982;66:174-8. [CrossRef]

10. Agrawal V, Wagh M, Krishnamachary M, Rao GN, Gupta S. Traumatic wound dehiscence after penetrating keratoplasty. Cornea 1995;14:6013. [CrossRef]

11. Tseng SH, Lin SC, Chen FK. Traumatic wound dehiscence after penetrating keratoplasty: clinical features and outcome in 21 cases. Cornea 1999;18:553-8. [CrossRef]

12. Rehany $\mathrm{U}$, Rumelt $\mathrm{S}$. Ocular trauma following penetrating keratoplasty: incidence, outcome, and postoperative recommendations. Arch Ophthalmol 1998;116:1282-6. [CrossRef]

13. Lam FC, Rahman MQ, Ramaesh $\mathrm{K}$. Traumatic wound dehiscence after penetrating keratoplasty-a cause for concern. Eye (Lond) 2007;21:114650. [CrossRef]

14. Schlote T, Rohrbach M. Traumatic glaucoma-a survey [Article in German]. Klin Monatsbl Augenheilkd 2005;222:772-82. [CrossRef]

15. Elder MJ, Stack RR. Globe rupture following penetrating keratoplasty: how often, why, and what can we do to prevent it? Cornea 2004;23:77680. [CrossRef]

16. Tran TH, Ellies P, Azan F, Assaraf E, Renard G. Traumatic globe rupture following penetrating keratoplasty. Graefes Arch Clin Exp Ophthalmol 
2005;243:525-30. [CrossRef]

17. Steinberg J, Eddy MT, Katz T, Fricke OH, Richard G, Linke SJ. Traumatic wound dehiscence after penetrating keratoplasty: case series and literature review. Eur J Ophthalmol 2012;22:335-41. [CrossRef]

18. Kawashima M, Kawakita T, Shimmura S, Tsubota K, Shimazaki J. Characteristics of traumatic globe rupture after keratoplasty. Ophthalmology 2009;116:2072-6. [CrossRef]

19. Filipec M, Phan TM, Zhao TZ, Rice BA, Merchant A, Foster CS. Topical cyclosporine A and corneal wound healing. Cornea 1992;11:546-52.

20. Gasset AR, Dohlman CH. The tensile strength of corneal wounds. Arch Ophthalmol 1968;79:595-602. [CrossRef]

21. Nagra PK, Hammersmith KM, Rapuano CJ, Laibson PR, Cohen EJ. Wound dehiscence after penetrating keratoplasty. Cornea 2006;25:132-5.
22. Liang H, Baudouin C, Daull P, Garrigue JS, Brignole-Baudouin F. Ocular safety of cationic emulsion of cyclosporine in an in vitro corneal woundhealing model and an acute in vivo rabbit model. Mol Vis 2012;18:2195204.

23. Kartal B, Kandemir B, Set T, Kuğu S, Keleş S, Ceylan E, Akmaz B, Apil A, Ozertürk Y. Traumatic wound dehiscence after penetrating keratoplasty. Ulus Travma Acil Cerrahi Derg 2014;20:181-8. [CrossRef]

24. Hiratsuka Y, Sasaki S, Nakatani S, Murakami A. Traumatic wound dehiscence after penetrating keratoplasty. Jpn J Ophthalmol 2007;51:1467. [CrossRef]

25. Watson AP, Simcock PR, Ridgway AE. Endothelial cell loss due to repeated traumatic wound dehiscence after penetrating keratoplasty. Cornea1987;6:216-8. [CrossRef]

\section{ORİJINAL ÇALIŞMA - ÖZET}

\section{Penetran keratoplasti sonrası travmatik yara yeri ayrilması}

\section{Dr. Evin Şingar Özdemir, ${ }^{1}$ Dr. Ayşe Burcu, ${ }^{1}$ Dr. Züleyha Yalnız Akkaya, ${ }^{1}$ Dr. Barış Oral, ${ }^{2}$ Dr. Firdevs Örnek'}

${ }^{1}$ Ankara Eğitim ve Araştırma Hastanesi, Göz Hastalıkları Kliniği, Ankara

${ }^{2}$ Ağrı Devlet Hastanesi, Göz Hastalıkları Kliniği, Ağrı

AMAÇ: Çalışmamızda, penetran keratoplasti (PK) sonrası künt travmaya bağlı yara açılmasını etkileyen faktörleri ve klinik sonuçları araştırmak amaçlanmıştır.

GEREÇ VE YÖNTEM: 1995-20I5 tarihleri arasında PK sonrası künt travmaya bağlı yara açması gelişen olgular geriye dönük olarak tarandı. Travma insidansı ve etiyolojisi, keratoplasti ve glob rüptürü arasındaki zaman, greft durumu, en iyi düzeltilmiş görme keskinliği (EDGK), komplikasyonlar, ikincil ameliyatlar ve yaralanma boyutunu etkileyebilecek faktörler kaydedildi.

BULGULAR: Çalışmaya yaş ortalaması 42.66 I6.66 yıl olan, 23'ü erkek, I6’sı kadın, toplam 39 hasta dahil edildi. Yara yeri açılma insidansı \%2.3 idi. Penetran keratoplasti ve travmatik yara yeri açılması arasındaki ortalama süre $25.91 \pm 47.24$ ay, ortalama takip süresi $34.43 \pm 51.02$ ay idi. En yaygın travma mekanizmasının künt bir nesnenin çarpması (\%53.8), en sık yara yeri ayrılmasının görüldüğü kadranın temporal (\%30.8) idi ve yara yeri ayrılma büyüklüğünün $45^{\circ}$ ile $270^{\circ}$ arasında olduğu saptandı. Hastalar yara yeri ayrılma büyüklügüne göre dört gruba ayrıldı; yara yeri ayrılma büyüklüğ̈̈ arttıkça, erkek cinsiyete daha sık rastlandığı, nazal ve üst kadranlarda yara yeri ayrılmasının daha sık görüldüğü, lens hasarının, arka segment komplikasyonlarının daha sık ve greft şeffaflı̆ının daha düşük oranda sağlandığı izlendi.

TARTIŞMA: Penetran keratoplasti sonrası ortaya çıkan travmatik yara yeri ayrılması nadir görülen ancak ömür boyu karşılaşlabilecek bir komplikasyondur. Göz kaybı gibi ciddi sonuçlar doğurduğundan, hastalar yara yeri ayrılma riskleri ve sekelleri açısından bilgilendirilmelidir.

Anahtar sözcükler: Penetran keratoplasti; travma; yara yeri ayrılması.

Ulus Travma Acil Cerrahi Derg 20 18;24(6):563-568 doi: 10.5505/tjtes.2018.44450 